\section{Beneficial Cardiovascular Effects of Low-dose Glucocorticoid Therapy in Inflammatory Rheumatic Diseases}

\section{To the Editor:}

We read with great interest the report by Mazzantini, et al ${ }^{1}$. That retrospective analysis of a large cohort of patients with polymyalgia rheumatica (PMR) demonstrated that duration or cumulative dose of longterm low-dose glucocorticoid (GC) therapy was significantly associated with higher risk of arterial hypertension and acute myocardial infarction. However, in a multivariate analysis adjusted for traditional cardiovascular (CV) risk factors, arterial hypertension was confirmed as the only adverse effect significantly associated with treatment duration.

It is thought that longterm GC treatment, especially at high dose, may indirectly increase the risk of $\mathrm{CV}$ disease through its well-recognized effect on traditional CV risk factors, including arterial hypertension, dyslipidemia, hyperglycemia, and obesity ${ }^{2}$. As summarized in Table 1, GC have been associated with higher incidence of subclinical atherosclerosis, and their detrimental effects on the $\mathrm{CV}$ system seem to occur at a preclinical phase. Although results are not uniform, duration of treatment exposure and higher cumulative dose are significantly correlated with higher risk of subclinical endothelial damage, the cumulative dose of prednisone being the only risk factor associated with progression of carotid intima-media thickness ${ }^{9}$. But whether and to what extent the subclinical endothelial dysfunction caused by GC affects the risk of overt $\mathrm{CV}$ events remains uncertain and unpredictable. Indeed, GC, especially at low dose, may exert a paradoxical cardioprotective effect through their antiinflammatory activity on the vessel wall. Interpretation of data is also hampered because some rheumatic immune-mediated inflammatory disorders, such as rheumatoid arthritis (RA) and systemic lupus erythematosus, represent per se an independent risk factor for atherosclerosis and $\mathrm{CV}$ disease ${ }^{10,11,12}$, making it difficult to distinguish between effects of GC and those of the underlying inflammatory and potentially proatherogenic disease.

In this context, data from studies investigating the harmful effect of GC on clinically manifested $\mathrm{CV}$ events are not conclusive, because there are no large randomized trials powered to detect differences in CV mortality and morbidity. Nevertheless, results from retrospective and case-control studies involving large cohorts of patients with chronic rheumatic and nonrheumatic inflammatory disorders (RA, PMR, connective tissue diseases, chronic obstructive pulmonary and inflammatory bowel disease) highlight the intriguing considerations (Table 2).

Specifically, after adjustment for confounders and traditional CV risk factors, a higher risk for $\mathrm{CV}$ events due to GC treatment appears to be shared by subjects with one of these heterogeneous conditions. Moreover, the risk appears more strictly associated with occurrence of heart failure than every other CV event, including myocardial infarction, stroke, transient ischemic attack, and peripheral artery disease. Continuous intake of $\mathrm{GC}$, oral GC administration, current exposure, and higher cumulative dose may represent variables significantly associated with higher risk of $\mathrm{CV}$ events. Finally, the adverse effects of GC on the CV system may differ according to the underlying disease for which they are prescribed. Notably, and similar to data from Mazzantini and colleagues, a retrospective analysis of a wide cohort of patients with PMR found no increased CV event risk associated with GC treatment, but a trend toward a protective effect of GC on the combined $\mathrm{CV}$ endpoints was observed ${ }^{21}$. Of interest, substantial risk reduction was demonstrated in patients exposed to GC for at least 1 year prior to the event compared to those never exposed ${ }^{21}$. It is conceivable that different pathogenic mechanisms underlying PMR in comparison to other inflammatory/autoimmune diseases may partially explain such discordant results. Indeed, it is well known that PMR is characterized by a high burden of inflammation that may reasonably predispose to functional and structural vascular endothelial alterations. This hypothesis is supported by our findings showing that aortic stiffness of patients with untreated PMR at disease onset was greater than that of matched healthy subjects, with a strong direct correlation between pulse-wave velocity and inflammatory markers ${ }^{22}$. The imbalance between endothelial fragmentation and repair, as assessed by increased endothelial microparticle (EMP) formation associated with reduced availability of endothelial progenitor cells (EPC) in our cohort, may be suggested as one of the pathogenic mechanisms involved in

Table 1. Glucocorticoid therapy and incidence of subclinical atherosclerosis

\begin{tabular}{|c|c|c|c|c|c|c|c|c|c|}
\hline Study & Type & $\begin{array}{c}\text { No. } \\
\text { Patients }\end{array}$ & $\begin{array}{c}\text { No. } \\
\text { Controls }\end{array}$ & Daily Dose & Cumulative Dose & $\begin{array}{c}\text { GC Duration, } \\
\text { yrs }\end{array}$ & $\begin{array}{c}\text { Subclinical } \\
\text { Atherosclerosis }\end{array}$ & Results & Comments \\
\hline $\begin{array}{l}\text { Gonzalez- } \\
\text { Juanatey } \\
2003^{3}\end{array}$ & $\begin{array}{l}\text { Case- } \\
\text { control }\end{array}$ & $\begin{array}{l}\text { RA } \\
47\end{array}$ & 47 & & $15.9 \mathrm{~g}$ mean & $\geq 5$ & $\begin{array}{l}\text { cIMT } \\
\text { plaque }\end{array}$ & $\begin{array}{c}\text { No correlation cumulative } \\
\text { PDN-plaque }\end{array}$ & \\
\hline $\begin{array}{l}\text { Gonzalez- } \\
\text { Juanatey } \\
2003^{4}\end{array}$ & $\begin{array}{l}\text { Case- } \\
\text { control }\end{array}$ & $\begin{array}{l}\text { RA } \\
55\end{array}$ & 31 & Mean $10 \mathrm{mg} /$ day & & $\geq 5$ & FMD & $\begin{array}{c}\text { No correlation cumulative } \\
\text { PDN-FMD }\end{array}$ & \\
\hline $\begin{array}{l}\text { del Rincon } \\
2004^{6}\end{array}$ & Prosp & $\begin{array}{l}\text { RA } \\
427\end{array}$ & 220 & Mean $6.4 \mathrm{mg}$ & $\begin{array}{l}\text { Low 5-6.0 mg, } \\
\text { medium } 6-16 \mathrm{mg} \text {, } \\
\text { high } 16-122 \mathrm{mg}\end{array}$ & Mean 7.5 & $\begin{array}{c}\text { cIMT, plaque, } \\
\text { ABI }\end{array}$ & $\begin{array}{l}\text { Increased plaque/ } \\
\mathrm{ABI} \text { in higher dose }\end{array}$ & $\begin{array}{l}\text { cIMT/plaque/ABI } \\
\text { with duration of } \\
\text { exposure }\end{array}$ \\
\hline $\begin{array}{l}\text { Hafström } \\
2007^{7}\end{array}$ & Prosp & $\begin{array}{c}\text { Early } \\
\text { RA } \\
34\end{array}$ & 31 & $\begin{array}{c}\text { DMARD + } \\
\text { PDN } 7.5 \mathrm{mg} / \text { day } \\
\text { vs DMARD }\end{array}$ & & $2 \pm 2$ & $\begin{array}{l}\text { cIMT plaque, } \\
\text { FMD }\end{array}$ & No difference & $\begin{array}{c}\text { Higher total } \\
\text { cholesterol in PDN }\end{array}$ \\
\hline $\begin{array}{l}\text { Giles } \\
2011^{9}\end{array}$ & Prosp & $\begin{array}{l}158 \\
\text { RA }\end{array}$ & No & & $\begin{array}{l}\text { Median } 3.1 \mathrm{~g} \\
\quad(0-9.1)\end{array}$ & & $\begin{array}{c}\text { cIMT/plaque } \\
\text { progression at } \\
\text { mean } 3.2 \text { yrs }\end{array}$ & $\begin{array}{l}\text { Association cumulative } \\
\text { PDN-cIMT } \\
\text { progression }\end{array}$ & $\begin{array}{l}\text { Lower cIMT } \\
\text { progression in PDN } \\
\text { users on statin therapy }\end{array}$ \\
\hline
\end{tabular}

cIMT: carotid intima-media thickness; ABI: ankle-brachial index; FMD: flow-mediated vasodilation; LVDD: left ventricular diastolic dysfunction; GC: glucocorticoid; PDN: prednisone; Prosp: prospective; RA: rheumatoid arthritis; DMARD: disease-modifying antirheumatic drug. 
Table 2. Glucocorticoid (GC) therapy and risk of cardiovascular (CV) events.

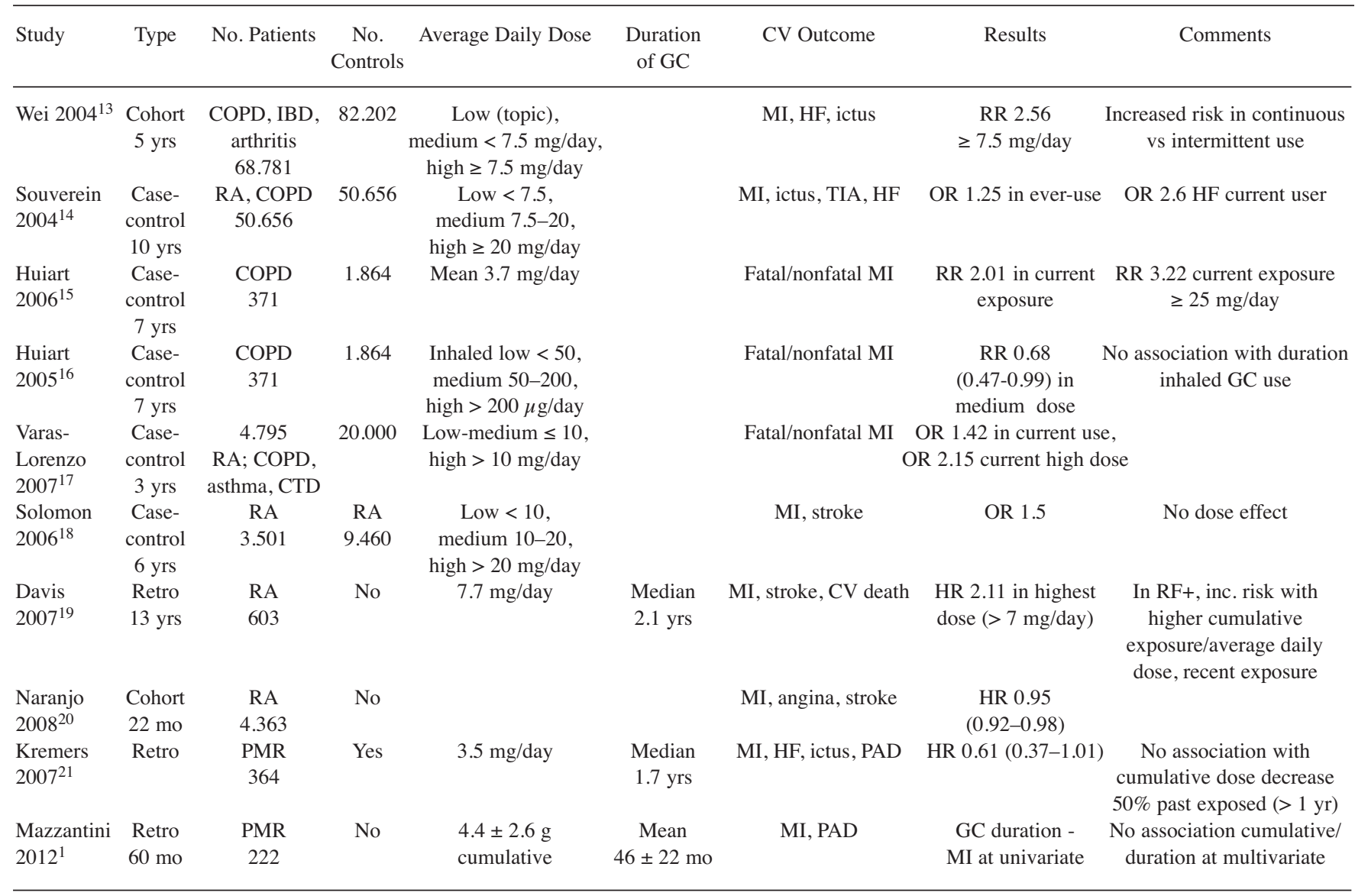

COPD: chronic obstructive pulmonary disease; IBD: inflammatory bowel disease; CTD: connective tissue disease; HF: heart failure; PAD: peripheral artery disease; MI: myocardial infarction; RA: rheumatoid arthritis; RF: rheumatoid factor; Retro: retrospective; RR: risk ratio; TIA: transient ischemic attack; HR: hazard ratio; PMR: polymyalgia rheumatica.

endothelial dysfunction ${ }^{9}$. Interestingly, a short treatment with low-dose GC was associated with consistent reduction of both arterial stiffness and the EMP/EPC ratio, suggesting beneficial effects on vascular endothelium homeostatis 22,23 .

Although a negative effect of longterm GC therapy on vascular tone and endothelial dynamic structure cannot be ruled out, rapid and profound inhibition of systemic inflammation induced by low-dose GC may quickly attenuate $\mathrm{CV}$ risk in systemic disorders characterized by high degree of inflammation. We believe that deeper knowledge of the effects of GC on the complex network of mechanisms leading to $\mathrm{CV}$ damage will be valuable in preventing $\mathrm{CV}$ events in patients with systemic inflammatory diseases.

ELENA BARTOLONI, MD; ALESSIA ALUNNO, MD; GIANLUCA SANTOBONI, MD; ROBERTO GERLI, MD, Rheumatology Unit, Department of Clinical and Experimental Medicine, University of Perugia, Via dal Pozzo, 06122 Perugia, Italy. Address correspondence to Dr. Gerli; E-mail: gerlir@unipg.it

\section{REFERENCES}

1. Mazzantini M, Torre C, Miccoli M, Baggiani A, Talarico R, Bombardieri S, et al. Adverse events during longterm low-dose glucocorticoid treatment of polymyalgia rheumatica: A retrospective study. J Rheumatol 2012;39:552-7.

2. van der Goes MC, Jacobs JW, Bijlsma JW. Toward safer treatment with glucocorticoids: Via patient and rheumatologist perspectives to recommendations on monitoring for adverse events. Clin Exp Rheumatol 2011;29:S116-S120.

3. Gonzalez-Juanatey C, Llorca J, Testa A, Revuelta J, Garcia-Porrua C, Gonzalez-Gay MA. Increased prevalence of severe subclinical atherosclerotic findings in long-term treated rheumatoid arthritis patients without clinically evident atherosclerotic disease. Medicine 2003;82:407-13.

4. Gonzalez-Juanatey C, Testa A, Garcia-Castelo A, Garcia-Porrua C, Llorca J, Vidan J, et al. HLA-DRB1 status affects endothelial function in treated patients with rheumatoid arthritis. Am J Med 2003; 114:647-52.

5. Gonzalez-Juanatey C, Testa A, Garcia-Castelo A, Garcia-Porrua C, Llorca J, Ollier WE, et al. Echocardiographic and Doppler findings in long-term treated rheumatoid arthritis patients without clinically evident cardiovascular disease. Semin Arthritis Rheum 2004;33:213-8.

6. del Rincón I, O'Leary DH, Haas RW, Escalante A. Effect of glucocorticoids on the arteries in rheumatoid arthritis. Arthritis Rheum 2004;50:3813-22.

7. Hafström I, Rohani M, Deneberg S, Wörnert M, Jogestrand T, Frostegård J. Effects of low-dose prednisolone on endothelial function, atherosclerosis, and traditional risk factors for atherosclerosis in patients with rheumatoid arthritis - A randomized study. J Rheumatol 2007;34:1810-6.

8. Vettori S, Maresca L, Cuomo G, Abbadessa S, Leonardo G, Valentini G. Clinical and subclinical atherosclerosis in systemic 
sclerosis: Consequences of previous corticosteroid treatment. Scand J Rheumatol 2010;39:485-9.

9. Giles JT, Post WS, Blumenthal RS, Polak J, Petri M, Gelber AC, et al. Longitudinal predictors of progression of carotid atherosclerosis in rheumatoid arthritis. Arthritis Rheum 2011;63:3216-25.

10. Bartoloni E, Alunno A, Luccioli F, Moscatelli S, Biscontini D, Santoboni G, et al. Atherosclerotic vascular damage and rheumatoid arthritis: A complex but intriguing link. Exp Rev Cardiovasc Ther 2010;8:1309-16.

11. Bartoloni E, Shoenfeld Y, Gerli R. Inflammatory and autoimmune mechanisms in the induction of atherosclerotic damage in systemic autoimmune diseases: Two faces of the same coin. Arthritis Care Res 2011;63:178-83.

12. Bartoloni E, Alunno A, Bistoni O, Gerli R. How early is the atherosclerotic risk in rheumatoid arthritis? Autoimmun Rev 2010;9:701-7.

13. Wei L, MacDonald TM, Walker BR. Taking glucocorticoids by prescription is associated with subsequent cardiovascular disease. Ann Intern Med 2004;141:764-70.

14. Souverein PC, Berard A, Van Staa TP, Cooper C, Egberts AC, Leufkens HG, et al. Use of oral glucocorticoids and risk of cardiovascular and cerebrovascular disease in a population based case-control study. Heart 2004;90:859-65.

15. Huiart L, Ernst P, Ranouil X, Suissa S. Oral corticosteroid use and the risk of acute myocardial infarction in chronic obstructive pulmonary disease. Can Respir J 2006;13:134-8.

16. Huiart L, Ernst P, Ranouil X, Suissa S. Low-dose inhaled corticosteroids and the risk of acute myocardial infarction in COPD. Eur Respir J 2005;25:634-9.
17. Varas-Lorenzo C, Rodriguez LA, Maguire A, Castellsague J, Perez-Gutthann S. Use of oral corticosteroids and the risk of acute myocardial infarction. Atherosclerosis 2007;192:376-83.

18. Solomon DH, Avorn J, Katz JN, Weinblatt ME, Setoguchi S, Levin $\mathrm{R}$, et al. Immunosuppressive medications and hospitalization for cardiovascular events in patients with rheumatoid arthritis. Arthritis Rheum 2006;54:3790-8.

19. Davis J, Maradit Kremers H, Crowson CS, Nicola PJ, Ballman KV, Therneau TM, et al. Glucocorticoids and cardiovascular events in rheumatoid arthritis: A population-based cohort study. Arthritis Rheum 2007;56:820-30.

20. Naranjo A, Sokka T, Descalzo MA, Calvo-Alén J, Hørslev-Petersen $\mathrm{K}$, Luukkainen RK, et al. Cardiovascular disease in patients with rheumatoid arthritis: Results from the QUEST-RA study. Arthritis Res Ther 2008;10:R30.

21. Kremers HM, Reinalda M, Crowson C, Davis J, Hunder G, Gabriel S. Glucocorticoids and cardiovascular events in polymyalgia rheumatic. Arthritis Care Res 2007;57:279-86.

22. Schillaci G, Bartoloni E, Pucci G, Pirro M, Settimi L, Alunno A, et al. Aortic stiffness is increased in polymyalgia rheumatica and improves after steroid treatment. Ann Rheum Dis 2012 Jan 20 [E-pub ahead of print].

23. Pirro M, Bocci EB, Di Filippo F, Schillaci G, Mannarino MR, Bagaglia F, et al. Imbalance between endothelial injury and repair in patients with polymyalgia rheumatica: Improvement with corticosteroid treatment. J Intern Med 2011 Dec 30 [E-pub ahead of print].

J Rheumatol 2012;39:8; doi:10.3899/jrheum.120192 